\title{
Vapaaehtoistyö oppimisen ja auttamisen areenana
}

\author{
Antti Eskola \& Leena \\ Kurki (toim. 2001). \\ Vapa a e h to is ty $\ddot{0}$ \\ auttamisena ja \\ oppimisena. $216 \mathrm{~s}$. \\ VASTAPAINO
}

\section{Antti Eskolan ja Leena}

Kurjen kirjan artikkelit ovat vapaaehtoistyön nimikkovuoden tärkeitä puheenvuoroja. Teokselle on ajan tilaus. Onkin kiitettävä Vastapainoa ja kirjan toimittajia ilmeisestä peräänantamattomuudesta kirjahankkeen toteuttamisessa. Vapaaehtoistyössä saadun oppimisen yhteiskunnallista hyötyä ei välttämättä ole huomattu, vaikka se on tuottanut monille perustavaa tieto-tai- toa myös työuralle. Kun otetaan huomioon vapaaehtoistyöstä syntynyt sosiaalinen pääoma ja sen piiristä löytyvä hiljainen tieto, millaiseksi sen yhteiskunnallinen arvo nouseekaan!

\section{Eskolan ja Kurjen}

kirjan näkökulma on yliopistomaailmasta. Kirjassa on kuitenkin antia ruohonjuuritason toimijallekin, sillä teoria ja käytäntö kytkeytyvät näkökulmien moninaisuudessa. Kirja soveltuukin vapaaehtoistyön peruskirjaksi aloittelijasta kokeneempaan toimijaan. Se ei suinkaan ole tyhjentävä, mutta se avaa ovia sellaiseenkin suuntaan, mitä kentällä ei tule huomanneeksi. Esimerkiksi lääketieteen, teologian tai arkkitehtuurin opiskelijalle vapaaehtoistyö tarjoaa oivalliset tuntosarvet arkielämään.

\section{Perinteisesti vapaa-} ehtoistyö on liitetty sosiaalialaan, mutta sielläkin se on varsin uusi alue. Kun lähdetään raaputtamaan hyvinvointivaltion historiallista pintaa, sieltä tulee esiin kansalaistoiminta innovaattorina ja toiminnan käynnistäjänä. Saattoi olla, että Suomen valtasi universalistisen hyvinvointivaltion lumo ja vapaaehtoistyö käsitettiin vielä kymmenkunta vuotta sitten hyvinvointivaltion rakentamisen esivaiheeksi. Tähän on tämän kirjoittajakin törmännyt sekä omassa 
ajatusmaailmassaan että aikanaan toimiessaan opettajana sosiaali- ja terveysalalla. Opetusohjelmissa vapaaehtoistyö jäi taka-alalle. Opiskelijoille on annettava tunnustus siitä, että he arvostivat sitä valitsemalla vapaavalintaisille käytännön opiskelujaksoilleen vapaaehtoistyön järjestöjä.

\section{Teos valottaa vapaa-}

ehtoistyön asemaa monien eri tieteenalojen näkökulmasta. Kirjan logiikka toimii. Se lähtee aluksi kartottamaan näkökulmia vapaaehtoistyöhön sosiaalipolitiikan, oikeustieteen ja kasvatuksen näkökulmista. Toisena kirjan jaksona on vapaaehtoistyön niveltäminen psykologian, kasvatustieteen, teologian, lääketieteen ja arkkitehtuurin koulutukseen. Oma lukunsa on naistutkimuksesta. Kolmannessa osassa pohditaan sitä, mitä vapaaehtoistyössä opittiin.

\section{Briitta Koskiaho tavoittaa} artikkelissaan vapaaehtoistyön yhteiskunnallisen paikan virallisen sosiaalityön liepeillä. Vapaaehtoistyötä tarkastellaankin kovin usein irrallaan yhteiskunnallisesta kontekstista ja ajassa olevista virtauksista. Saman olen minäkin huomannut liikkuessani eri vapaaehtoistyön verkostoissa. Vapaaehtoistyön paikkaa yhteiskunnassa ei pitäisi kuitenkaan tarkastella ilman ajan suuntauksia. Koskiaho ottaakin tarkastelussaan mukaan uusliberalismin, sosiaaliliberalismin ja kommunitarismin. Viime mainitusta suuntauksesta keskusteltiin muutama vuosi sitten vilkkaasti, mutta nyttemmin keskustelu tuntuu laantuneen. Toivottavaa onkin, että vapaaehtoistyön paikkaa sekä toiminnallisesti että filosofi- sesti mietittäisiin edelleen. Koskiahon artikkeli on tähän yksi esimerkki. Tarkan paikan määrittämiseen ei kuitenkaan ole tarvetta eikä mahdollisuuttakaan, sillä vapaaehtoistyön raja markkina- ja yhteiskuntavetoisiin sektoreihin on häilyvä.

Vapaaehtoistyön ja liikeelämän suhdetta pohtivat kirjassa Arja Repo ja Päivi Eriksson. He päätyvät toteamaan, että sekä liike-elämä että vapaaehtoistyö voivat oppia toisiltaan. Erityisesti kirjan talouselämään liittyvää artikkelia lukiessa tulee mieleen käsiteongelmat. Kirjoittajat puhuvat johdonmukaisesti vapaaehtoistyöstä. Talouden määritteissä tämä sijoitetaan kolmannen sektorin talouteen. Kuitenkin myös vapaa-ehtoisjärjestöillä on liiketoimintaan rinnastettavaa toimintaa, mikä kenties ei kuulu kolmanteen sektoriin, tai sitten käsitteitä on täsmennettävä. Kirjoittajat toteavat, että vapaaehtoistyössäkin voidaan toimia liikeyrityksen tavoin ja omaksua sieltä johtamisoppinsa. Miten siinä sitten käynee aatteellisuuden?

\section{Vapaaeh toistyöntekijän} oikeudellista asemaa pohdiskelee Hannu Tapani Klami tarkastellessaan palkattoman työn oikeusturvaa. Oikeudelliset kysymykset mm. työoikeuden näkökulmasta ovat nyttemmin entistäkin ajankohtaisempia, sillä vapaaehtoistyön kentällä sukkuloi ihmisiä sekä palkkatyöntekijöinä että vapaaehtoisina. Monien oikeudellinen asema vaihtelee, jolloin ihminen itse ei välttämättä ole notee-rannut asemansa muuttumisen merkitystä. Toimijoiden ja organisaatioiden vas- tuukysymysten selvittäminen on ajankohtainen koulutuksellinen haaste. On kaikkien kannalta hyvä selvittää, mitä kyseinen työ on ja mitkä ovat oikeudelliset normit sitä tehdessä. Hannu Tapani Klami persoonalleen uskollisena ei jää pohtimaan vain oikeuden normeja, vaan hänen artikkelinsa henki on myös oikeuseettinen.

\section{Leena Kurki avaa}

osuudessaan vapaaehtoistyön ovia opetukseen. Vaikka hänen näkökulmanaan onkin yliopisto-opetus, teksti sopii muullekin opetuksen ja kasvatuksen alueelle. Taustalla Kurjen tekstissä on jesuiittojen tekemän vapaaehtoistyön ja siihen kasvamisen kokemukset. Juuret ovat uskonnolliset ja juontavat ikivanhaan armeliaisuustyöhön. Humanismi ja eräänlainen subjektivismi olisikin saatavissa opetukseen vapaaehtoistyön kautta.

\section{Leena Kurjen artikkelissa} näkyy käsitemäärittelyjen merkitys. Esimerkiksi solidaarisuus-sanaa tulee usein käyttäneeksi löysästi miettimättä, mitä se todella tarkoittaa. Leena Kurki katsoo vapaaehtoistyön perustana olevan solidaarisuuden, joka ei ole äkillinen myötätunnon tunne ja ele, vaan se on käsitettävä positiiviseksi utopiaksi, näyksi paremmasta maailmasta. Vaarana luonnollisesti on ajautuminen idealismiin, minkä vuoksi opetuksessa tulee olla riittävä annos realismia. Leena Kurjen tekstiä lukiessa jäikin omaatuntoa kaivelemaan se, olemmeko nyky-yhteiskunnassa kadottaneet aidon solidaarisuuden sisällön. Me lähdemme herkästi mukaan erilaisiin sinänsä hyviin kampan- 
joihin ja projekteihin lyhyeksi ajaksi, mutta emme halua sitoutua paremman maailman tavoitteeseen. Joskus tuntuukin siltä, että taidamme olla huonoa omaatuntoamme paikataksemme ns. "osa-aikasolidaarisia", kun ihmisenä olemiseen pitäisi kuulua "kokoaikasolidaarisuus" kanssaihmisiä kohtaan.

\section{Kirjan toinen osa}

pureutuu eri alojen mahdollisuuksiin vapaaehtoistyöstä oppimisen areenana. Markku Ojasen näkökulmana on psykologian opetus ja vapaaehtoistyö. Hän toteaa, ettei vapaaehtoistyölle ole siinä ollut sanottavammin tilaa. Psykologiassa ihminen on nähty Freudista lähtien itsekkäänä olentona, jolla ei ole kykyjä auttaa itseään eikä lähimmäisiäänkään, vaan se on asiantuntijoiden tehtävä. Nyttemmin psykologiankin viitekehykseen näyttää tulleen käsityksiä, jotka antavat tilaa auttamistyölle. Kari Uusikylä jatkaa uusien urien avaamista kutsumalla vapaaehtoisia kasvatusalalle. Uusikylän teksti on muutoin akateemiselta tuntuvassa kokoelmassa poikkeuksellinen. Siinä on muita tekstejä vahvempi inhimillinen viritys. Uusikylän mielestä opiskeluun tarvitaan humaanimpaa otetta markkinavetoisuuden sijaan. Esko Koskenvesalla on tärkeä teologian näkökulma. Tuleville hengellisen työn tekijöille vapaaehtoistyöstä löytyy aitoa "pelaajakokemusta". Vapaaehtoistyön merkitystä opiskelussa korostaa se, että monet kirkkojen toiminnot ovat vapaaehtoisten varassa niin kirkossa kuin vapaissa suunnissakin. Staffan Lodenius valottaa omaehtoistoi- mintaa kotikadulla ja sen antia arkkitehtikoulutuksessa ja $\mathrm{Ka}$ rina Kailo tuo naistutkimuksen näkökulman. Vapaaehtoisista naiset ovat enemmistönä, mutta monelle miehellekin vapaaehtoistyö tarjoaa tervetulleen toiminnallisen areenan.

\section{Kirjan kolmas osa}

käsittelee yliopisto-opiskelijoiden saamaa antia vapaaehtoistyöstä. Juha Nieminen kertoo artikkelissaan opiskelijoista "ylös, ulos ja kentälle"-lähtijöinä. Otsikko kytkee yhteen vapaaehtoistyön käytännön ja teorian, mikä on artikkelin keskeisintä antia. Samaa osoittaa toinenkin aihetta käsittelevä artikkeli, jossa Timo Ahonen ja Eeva Valjakka kertovat, miten oikeustieteen ylioppilas kohtaa ihmisen vapaaehtoistyön kautta. Kirjan sinetiksi voidaan nostaa Antti Eskolan artikkeli vapaaehtoistyöstä oppimisen sosiaalipsykologiana. Eskola tiivistää vapaaehtoistyön merkityksen niin, että se opettaa opiskelijoille "prososiaalista käyttäytymistä". Tällä hän tarkoittaa sitä, että ollaan valmiita auttamaan lähimmäisiä, vaikka auttaminen on tekona epäitsenäinen tai auttamisen kannustimena on mielihyvää tuottava altruismi.

\section{Toimittajat ansaitsevat} kiitoksen intomielisyydestään. Asiaan vihkiytyneisyyttä on varmasti tarvittu, sillä markkina-arvoihin perustuvassa nykymaailmassa teema ei ole myyvimpiä. Vastapaino ansaitsee samoin kiitokset kustantajana rohkeudestaan. Tämä on jälleen yksi osoitus kustannusliike Vastapainon merkityksestä. Kirja johdattelee osaltaan vapaaehtoistyön syviin merkityksiin, kuten sosiaalisen pääoman ja hiljaisen tiedon lähteille, vaikka näitä teemoja ei kirja varsinaisesti käsittelekään. Kirja kulkee johdonmukaisesti vapaaehtoistyön "nimilapun" alla, vaikka alueen yksi keskeisimmistä ongelmista on käsitteellinen hämäryys.

\section{Vapaaehtoistyö ja}

kolmas sektori eivät ole käsitteinä sama asia. Viitteitä tämän rajanvedon ongelmaan on kirjassakin. Vapaaehtoistyön teemavuoden 2001 julkisuuden käsittelyssä tämä ongelma näkyi usein ja siksi Antti Eskolan ja Leena Kurjen toimittaman kirjan luku Johdannoksi kannattaa lukea erityisen huolellisesti. Siinä määritellään lähtökohdat erinomaisesti, mitä useinkaan me innolla vapaaehtoistyöstä kirjoittajat ja puhujat emme muista tehdä. Kirja "Vapaaehtoistyö oppimisena ja auttamisena" avaa ovia kasvatuksen alueelle, mikä on saatettu usein unohtaa vapaaehtoistyön piirissä. Kirja osaltaan toteuttaa "vapaaehtoispedagogiikkaa", jolle teoreettinen kehys löytyy sosiaalipedagogiikasta. Vapaaehtoisorganisaatiot ovat luonteeltaan sosiaalisia, joten pedagoginen näkökulma tuo monipuolisuutta. Jatkolukemiseksi suosittelen myös sosiokulttuurista innostamista ja sosiaalipedagogiikkaa käsitteleviä erinomaisia teoksia. Keskustelu vapaaehtoistyöstä jatkukoon!

Heikki Kemppainen 